\title{
La libertad de expresión en el contexto del modelo de comunicación político-electoral
}

\author{
Freedom of Speech in the Context \\ of the Political-Electoral Communication Model
}

César Astudillo*

\section{Sumario:}

I. Introducción

II. El modelo de comunicación político-electoral y sus implicaciones con el ejercicio de la libertad de expresión

III. La libertad de expresión y su limitación a través de la regulación constitucional y legal

IV. El modelo de comunicación política no vulnera la libertad de expresión

V. Deficiencias institucionales que no favorecen la fluidez de la libertad de expresión en su manifestación políticoelectoral

VI. Conclusiones

* Esta contribución se enmarca en el proyecto de investigación "La libertad de expresión y sus principales manifestaciones en el contexto de la democracia mexicana”, patrocinado por el Fondo de Apoyo a la Observación Electoral 2012, administrado por el Programa de Naciones Unidas para el Desarrollo (PNUD).

Recibido: 10 de noviembre de 2012

Aceptado: 14 de diciembre de 2012 


\section{Resumen:}

Desde su implantación en la reforma electoral de 2007, el modelo de comunicación político-electoral ha sido objeto de polémica. Sus detractores afirman que vulnera la libertad de expresión al prohibir la comunicación política a través de la libre contratación de spots electorales; quienes lo respaldan, por el contrario, sostienen que el modelo es compatible con aquellos sistemas democráticos que auspician la paridad de condiciones en la competencia política e impiden que el factor oneroso sea determinante en las posibilidades de triunfo de sus contendientes. Este trabajo ofrece argumentos para afirmar que el nuevo modelo no vulnera la libertad de expresión, sino que la modula en concordancia con el principio constitucional de equidad; no obstante, se detiene a analizar aquellas deficiencias institucionales que no favorecen la fluidez de la comunicación en el espacio político-electoral, y que dificultan la circulación de una mayor riqueza de contenidos y una información de mayor calidad, elementos indispensables para la emisión de un voto consciente y razonado.

\section{Abstract:}

The political-electoral communication model has been controversial since its approval in the 2007 electoral reform. Its detractors sustain that this model weakens freedom of speech by forbidding political communication through the free purchase of TV and radio airtime by political parties. However, its supporters argue that this model is consistent with democratic systems that promote equal conditions and prevent campaign spending from determining the winners in the political competition. This article provides arguments to affirm that the new model does not limit freedom of speech but, rather, that it modulates it according to the constitutional principle of fairness. Additionally, this article analyzes the institutional deficiencies that do not encourage the flow of communication in the political-electoral arena, and that hinder the circulation of richer contents and more valuable information, both essential elements of a conscious and reasoned vote.

Palabras clave: libertad de expresión, modelo de comunicación político-electoral, equidad electoral, reforma electoral de 2007, propaganda político-electoral, spots electorales.

Keywords: freedom of speech, political-electoral communication model, 2007 electoral reform, political-electoral advertisement, electoral spots. 


\section{Introducción}

En noviembre de 2007 se publicó una nueva reforma constitucional en materia electoral que tuvo como elemento vertebrador la introducción de un nuevo "modelo" de comunicación político-electoral dirigido a redefinir la relación de los sujetos políticos, los medios de comunicación, los ciudadanos y las autoridades electorales dentro de un espacio público necesitado de más y mejor calidad en la deliberación de los asuntos que por ser de naturaleza pública, atañen a la sociedad en su conjunto. ${ }^{1}$

A cinco años de distancia la ponderación de su funcionamiento y los resultados arrojados respecto al cumplimiento de los medios de comunicación conducen a señalar que es un modelo incorporado con éxito al andamiaje electoral mexicano. No obstante, el análisis arroja otro tipo de conclusiones desde la lógica para la que dicho modelo está pensado, si advertimos que su orientación debe permitir más y mejores canales para la deliberación pública, el contraste de opiniones y propuestas políticas, el envío de información de contenido político y la socialización de mensajes dirigidos a influir en la voluntad del ciudadano-elector.

En efecto, desde esta perspectiva, si bien las premisas del modelo son profundamente compatibles con un Estado democrático de derecho legitimado a partir del reconocimiento, garantía y maximización de los derechos y libertades de las personas - entre ellas evidentemente la libertad de expresión-, en un contexto caracterizado por la existencia de principios constitucionales que auspician la paridad de condiciones en la competencia política, la regulación del modelo deja entrever que contiene elementos que no favorecen la fluidez, flexibilidad, oportunidad y maximización de la libertad de expresión en el contexto de la comunicación político-electoral.

Lo apenas señalado debe entenderse en su correcta dimensión. Desde nuestra perspectiva, el modelo debe mantener sus premisas esenciales, que son compatibles con el Estado constitucional y democrático de derecho por derivar de las democracias más consolidadas, pero

1 La noción de "modelo" que se emplea tiene por objeto presentar las distintas pie$z a s$ que definen la relación entre los sujetos aludidos de manera coherente, ordenada y articulada en función de las premisas en que se asientan y los fines a los que se dirigen. 
debe ser sometido a una adecuada revisión para hacer que cumpla con los objetivos que está llamado a satisfacer dentro de una sociedad cada vez más plural y democrática como la mexicana.

No debe pensarse en una involución en la materia. Por el contrario, debemos pensar en los ajustes necesarios para adecuar el modelo a las exigencias de una comunicación de mayores contenidos informativos, sobre todo si la razón última del modelo tiene como propósito la construcción de una ciudadanía informada y en posibilidad de emitir un voto razonado y de calidad.

En este contexto, el trabajo que se presenta abordará el inescindible vínculo existente entre la libertad de expresión y el modelo de comunicación político-electoral para, enseguida, reflexionar sobre aquellas deficiencias institucionales que no incentivan e, incluso, obstaculizan la libertad de expresión en el ámbito electoral.

\section{El modelo de comunicación político-electoral y sus implicaciones con el ejercicio de la libertad de expresión}

Por comunicación política se entiende, con Mazzoleni, "el intercambio y la confrontación de los contenidos de interés público-político que produce el sistema político, el sistema de los medios y el ciudadanoelector". ${ }^{2}$ El sistema político comprende al conjunto de instituciones políticas que interactúan en la vida pública de un país y se representa en los poderes del Estado, los partidos políticos, grupos de presión y los candidatos; el sistema de medios se entiende como el conjunto de instituciones mediáticas que desarrollan actividades de producción y socialización de información, ideas, cultura, y se compone por medios de comunicación como la televisión, la radio, la prensa, la Internet, entre otros; por su parte, el ciudadano-elector es aquella persona que cumple con los atributos para participar políticamente dentro de una comunidad determinada, sea en forma individual o a través de grupos o asociaciones. ${ }^{3}$

2 Cfr. Mazzoleni, Gianpietro, La comunicación política, trad. de Josefa Linares de la Puerta, Madrid, Alianza, 2010, p. 36.

3 Cfr. ibidem, pp. 30 y ss. 
La comunicación política se interesa por el papel que ejerce la comunicación dentro del proceso político; estudia principalmente la manera como la política es comunicada por quienes la ejercen - los políticos-, por quienes la transmiten - los medios de comunicación-y por quienes la reciben - los ciudadanos-. ${ }^{4}$

La comunicación político-electoral es relevante porque no existe ninguna sociedad democrática que no precise de una "esfera pública"5 en donde la ciudadanía dialogue abiertamente sobre cuestiones de interés colectivo. Dicho espacio y las modalidades de comunicación que posibilitan la interacción entre las instituciones gubernamentales, electorales, políticas, los gobernantes, dirigentes, candidatos y la ciudadanía, son esenciales para la democracia.

La función pública que desempeñan los primeros, o la necesidad de ser escuchado y reconocido por la sociedad, típica de los últimos, hacen inevitable la circulación de una multiplicidad de comunicaciones con diversos significados, mensajes, implicaciones y finalidades. Los agentes de la política necesitan un canal de comunicación con el ciudadano, pieza clave del entramado democrático por su calidad de elector, ante quien se despliegan debates y deliberaciones, se presentan discursos y se allega información con el objetivo de mantener su interés en lo que acontece en la escena pública para que, llegado el momento, esté en aptitud de manifestar su adhesión a las decisiones tomadas o expresar su simpatía por una determinada fuerza política al interior de una campaña electoral.

Como consecuencia de lo anterior, un rasgo distintivo de la democracia reside en su inescindible vinculación con la comunicación política, la cual, a su vez, presupone un régimen de libertades plenas amparadas por el orden constitucional. Dentro de dicho concierto de libertades públicas, la libertad de expresión adquiere una relevancia significativa al ofrecer la cobertura jurídica para que las personas exterioricen libremente sus ideas, pensamientos y críticas. Es, de hecho, la libertad fundamental que posibilita la interacción de la política con el ciudadano dentro de una esfera pública determinada porque le permite hacerse de una determinada cosmovisión del mundo, configu-

4 Véase Chaffe, S. (comp.), Political comunication, Beverly Hills, Sage, 1975, p. 15; en general, Rospir, J. I., "Introducción a la comunicación política”, en Salomé Berrocal, Gonzalo (coord.), Comunicación política en televisión y nuevos medios, Barcelona, Ariel, 2003.

5 En torno a la noción de "esfera pública", acúdase a Habermas, Jürgen, Storia e critica dell'opinione pubblica, Roma-Bari, Laterza, 1974. 
rar un conjunto de creencias personales, exteriorizar el propio pensamiento, proyectar su libertad ideológica y materializar los valores democráticos de la sociedad. Es, por tanto, una libertad pública incuestionable y, a su vez, el fundamento de otras libertades públicas igualmente relevantes para el orden democrático, como la libertad de reunión y asociación, el derecho a la información, la libertad de imprenta, el derecho a la honra, la dignidad y, como correlato, los derechos de participación política. ${ }^{6}$ De ahí que su global consideración las agrupe en un régimen de libertades de más amplio alcance y las erija en auténticas libertades de comunicación, sean públicas o sociales. ${ }^{7}$

La libertad de expresión otorga la cobertura jurídica para allegarse información que permita comprender lo que ocurre en el espacio político, expresar convicciones y creencias, procesar los actos de gobierno, adherirse a ellos o criticarlos, exigir rendición de cuentas, dejarse influir por los mensajes políticos, interactuar con otros sujetos de su entorno, filtrar la información proveniente de los medios de comunicación, participar en la dialéctica de las redes sociales y, en definitiva, ejercer un voto consciente, razonado e informado como manifestación primigenia del principio de soberanía depositada en quienes conforman el cuerpo social. ${ }^{8}$

En el ámbito de la competencia electoral, la libertad de expresión permite socializar mensajes de contenido político, difundir programas, ideologías y plataformas, confrontar ideas y propuestas de campaña, ejercer la crítica hacia los miembros de la clase política y los partidos políticos, debatir en torno a los resultados de la gestión pública, transmitir spots con voces o imágenes propagandísticas, enviar información con contenido electoral, entrar en diálogo directo con los candidatos y sus partidos y, en el extremo, posibilitar la expresión de las preferencias políticas mediante el ejercicio directo del sufragio. Como consecuencia de lo anterior, allí donde el ejercicio de la

6 La Sala Superior del TEPJF ha reconocido que la honra y la reputación se reconocen dentro del ejercicio de la libertad de expresión, en la jurisprudencia 14/2007, HonRA Y REPUTACIÓN. SU TUTELA DURANTE EL DESARROLLO DE UNA CONTIENDA ELECTORAL SE JUSTIFICA POR TRATARSE DE DERECHOS FUNDAMENTALES QUE SE RECONOCEN EN EL EJERCICIO DE LA LIBERTAD DE EXPRESIÓn, TEPJF, año 1, núm. 1, 2008, pp. 24 y ss.

7 Polo Sabau, José Ramón, Libertad de expresión y derecho de acceso a los medios de comunicación, Madrid, Centro de Estudios Políticos y Constitucionales, 2002, pp. 15 y ss.

8 Carbonell, Miguel, "La libertad de expresión en materia electoral”, Temas selectos de Derecho Electoral, núm. 3, México, TEPJF, 2010, p. 8. 
libertad de expresión es robusto el sistema democrático se enriquece; pero se consolida únicamente en la medida en que logre garantizar el goce efectivo de derechos y libertades políticas. En este sentido, la recíproca implicación entre la libertad de expresión y la democracia es evidente.

El intercambio de opiniones, la deliberación y discusión en el espacio público sólo es posible en un entorno donde las libertades están institucionalizadas, donde la clase política privilegia la apertura de canales de comunicación con la sociedad, los medios de comunicación realizan la función social que les ha sido conferida y los ciudadanos mantienen la exigencia de allegarse información como precondición para interactuar en el espacio público.

Más allá de su función clásica, jurídica-negativa, la libertad de expresión despliega una función jurídica-positiva que enaltece su relevancia fundamental para el régimen democrático en cuanto constituye el presupuesto necesario para la conformación de una opinión pública robusta y vigorosa, elemento basilar del Estado democrático de derecho. ${ }^{9}$ A su vez, la opinión pública es la condición inexorable para la edificación del pluralismo político, elemento consustancial del sistema representativo. Ambas proyecciones permiten afirmar que estamos delante de una libertad esencial, y a la vez instrumental del edificio constitucional. ${ }^{10}$

A la comunicación política le interesa la libertad de expresión desde sus dos dimensiones, pero le resulta más significativa la que se vincula con el contexto electoral y con el ejercicio de los derechos de naturaleza política. Recordemos que las elecciones representan un instrumento al servicio del principio democrático y que la legitimidad de los comicios depende, en buena medida, del ejercicio de las libertades políticas y de la especial intensidad de su empleo previo al llamado de las urnas; de ahí que sea en el ámbito de las campañas electorales donde el ejercicio de la libertad de expresión se agudiza, ensancha e intensifica para permitir el flujo más amplio de información entre los ciudadanos y los aspirantes a cargos de elección popular, y que en el ámbito del debate político-electoral, el ámbito de tolerancia fren-

9 Sobre la doble función de los derechos, Grimm, Dieter, “¿Retorno a la comprensión liberal de los derechos fundamentales?", Constitucionalismo y derechos fundamentales, estudio preliminar de Antonio López Pina, Madrid, Trotta, 2006, pp. 155 y ss.

10 Llamazares Calzadilla, María Cruz, Las libertades de expresión e información como garantía del pluralismo democrático, Madrid, 1999, pp. 43 y ss. 
te a juicios valorativos, apreciaciones o aseveraciones producto de la confrontación política, adquiera un notable redimensionamiento para que contribuya a la discusión de temas de interés público dentro de una sociedad democrática. ${ }^{11}$

Es esta relevancia adquirida por la libertad de expresión la que lleva a reconocerle una especial dignidad dentro del concierto de las libertades fundamentales. No es, por tanto, una libertad más, sino un pilar y fundamento del orden político en tanto condición necesaria para el mantenimiento y la consolidación de las instituciones democráticas, y un derecho esencial del sistema constitucional cuyo empleo permite medir la vitalidad y salud del edificio democrático.

Lo anterior conduce a situar a la libertad de expresión en un lugar preponderante dentro del sistema constitucional, lo cual no implica que jerárquicamente sea superior a otras libertades, sino que se pondere la función que desempeña en el contexto democrático cuando entre en colisión con otros derechos y libertades, a fin de que su contenido no se desnaturalice, ni su relevancia se relativice de forma injustificada. ${ }^{12}$

Importante es destacar que la libertad de expresión se potencia a través de los canales de comunicación de masas, en donde los medios de comunicación adquieren una influencia decisiva para descubrir o encubrir información de relevancia pública, minimizar o ensanchar el discurso político, enriquecer o debilitar el debate público. Si bien los medios no constituyen el espacio público, necesario es subrayar que contribuyen a crearlo. Son canales privilegiados para generar una comunicación que permita consolidar corrientes de información y de opinión tanto dentro como fuera de las campañas electorales. Fuera de las campañas contribuyen a socializar la perspectiva y el posicionamiento de los actores políticos en función de sus premisas ideoló-

11 Jurisprudencia 11/2008, Tribunal Electoral del Poder Judicial de la Federación, año 2, núm. 3, 2009, pp. 20 y 21, rubro: LibERTAD DE EXPRESIÓN E INFORMACión. Su MAXIMIZACIÓN EN EL CONTEXTO DEL DEBATE POLÍTICO.

12 La Sala Superior del TEPJF, ha sostenido una tesis distinta en la sentencia SUPJDC-393/2005 al subrayar que a la libertad de expresión se le debe reconocer una "posición preferente" frente a otros derechos, lo cual, hay que decirlo, destaca la jerarquía de aquella en detrimento de un adecuado ejercicio de ponderación ante la eventualidad de colisiones entre derechos fundamentales. En respaldo de esta posición, acúdase a Carbonell, Miguel y Vado Grajales, Luis Octavio, "Libertad de expresión, partidos políticos y democracia. Comentario a la sentencia JDC-393/2005 del TEPJF", Serie Comentarios a las sentencias del Tribunal Electoral, núm. 45, México, TEPJF, 2012. 
gicas y plataformas de gobierno. Dentro de las campañas auspician la generación del debate político, coadyuvan a presentar y dar forma a las agendas político-electorales de los contendientes, y sobre todo, retroalimentan al ciudadano para que pueda desplegar su ejercicio de elección política de forma consciente, informada y razonada.

La preeminencia de los medios masivos de comunicación es cada vez más relevante si se toma en cuenta la transformación de su función original; de ser agentes de intermediación entre el sistema político y los ciudadanos, se han erigido en el espacio donde discurre y se representa la actuación política y en donde las posibilidades de éxito de sus protagonistas depende, en buena medida, de la actuación de dichos medios. ${ }^{13}$

La irrupción de emergentes y modernos medios de comunicación, propios del avance de las tecnologías de la información, ha venido a ensanchar el espacio público y a superar los límites impuestos por la exclusiva interacción en la política de la radio y televisión, propiciando una interacción ciudadana más activa, ávida de construir renovados canales de opinión, de redimensionar la influencia de la comunicación política en la vida pública y ensanchar los márgenes de participación ciudadana en el sistema democrático.

La pluralidad de medios de comunicación es esencial en este contexto. Su implantación permite que el ciudadano abreve de una diversidad de fuentes informativas, en concordancia con la pluralidad que se expresa dentro de la propia sociedad. La heterogeneidad política y social constituye el elemento catalizador de una opinión pública informada y vigorosa en la que se garantice la vigencia efectiva del pluralismo ideológico, valor indiscutible de la democracia, y en la que se reafirme la neutralidad del Estado a través de la eliminación de aquellos privilegios que mantienen un sistema manifiestamente endogámico de medios de comunicación.

13 Por ello, Mazzoleni distingue un modelo de comunicación política "propagandístico-dialógico" y un modelo "mediático", La comunicación política..., cit., pp. 26 y ss. Sobre las consecuencia de la era mediática de la política, García Beaudoux et. al., Comunicación política y campañas electorales. Estrategias en elecciones presidenciales, Barcelona, Gedisa, 2007 , p. 28. 


\section{La libertad de expresión y su limitación a través de la regulación constitucional y legal}

Se ha señalado que la libertad de expresión tiene una dimensión individual y una dimensión pública o social, de conformidad con la función que cada una debe de cumplir, tanto en su calidad de esfera de libertad para la expresión del pensamiento protegida contra cualquier injerencia arbitraria de los poderes públicos, como en carácter de presupuesto indispensable para la conformación de una comunicación política libre, en beneficio del pluralismo político que caracteriza a cualquier sociedad democrática.

Para que la libertad de expresión ejerza sus potencialidades en cada dimensión se requiere la intervención legislativa, sea constitucional $\mathrm{u}$ ordinaria, que mediante reglas formales racionalice el ejercicio de la misma de conformidad con los distintos ámbitos en los que se manifiesta. La regulación en el ámbito político-electoral es fundamental, no sólo porque en esta esfera los influjos de la libre manifestación del pensamiento se ensanchan, sino porque al propio ordenamiento jurídico le corresponde ampliar las vías para la expresión de las ideas de determinados sujetos políticos, abrirlas para el debate, la propuesta, la confrontación, la crítica; maximizar los canales para la libre circulación de información electoral, limitar las voces que pueden enviar mensajes de contenido político, o bien restringir el contenido de dichos mensajes.

No obstante, la precomprensión del contenido y alcances de la libertad de expresión es fundamental para determinar el grado de intervención legislativa que para su ejercicio puede resistir y que se aprecia nítidamente en el andamiaje normativo que soporta al modelo de comunicación político-electoral.

En efecto, si se concibe que la libertad de expresión tiene una posición preferente dentro del sistema democrático y que goza de una protección reforzada frente a otros derechos, principios y fines del ordenamiento jurídico, como acontece en el sistema estadounidense, las posibilidades de regulación jurídica disminuyen ante el rechazo radical a toda modalidad que pretenda limitar la influencia de la primera enmienda de la Constitución. De ahí que el sistema, bajo la premisa de que todos tienen la misma posibilidad de expresarse políticamente, permita el acceso irrestricto a los medios masivos de comunicación, 
libere la contratación de propaganda electoral y prohíba la limitación de gastos para actividades de promoción política. Si se entiende, por otro lado, que la libertad de expresión constituye una libertad que en el espacio público debe garantizar que la dialéctica entre los contendientes políticos no se encuentre condicionada por el dinero, se justifica una intervención más fuerte del legislador para establecer reglas precisas para eliminar el factor oneroso en el acceso de los medios de comunicación y para generar la paridad de condiciones en la competencia política. Lo anterior es posible donde la libertad de expresión no tiene reconocida una preponderancia formal, condición necesaria para que pueda ser armonizada con otros derechos y libertades, o con principios específicos del ámbito electoral, como el principio de equidad en la contenida. ${ }^{14}$

De conformidad con lo anterior, la libertad de expresión en el contexto de la política encuentra una regulación normativa más o menos incisiva, con limitaciones e incluso prohibiciones puntuales, de conformidad con los márgenes de ensanchamiento o modulación de la libertad de expresión que se quieren introducir en razón de la naturaleza, el papel y la función que se le reconoce en cada sistema constitucional.

La reforma electoral de noviembre de 2007, constata una intervención fuerte del legislador constitucional mexicano a la cobertura jurídica de la libertad de expresión, al establecer una regulación precisa sobre: a) la modalidad de acceso de los partidos políticos a los medios de comunicación, particularmente la radio y televisión; $b$ ) la

14 En torno a la compresión de la libertad de expresión y su influencia en los modelos de comunicación política, acúdase a Astudillo, César, "El nuevo sistema de comunicación política en la reforma electoral 2007-2008”, en Córdova Vianello, Lorenzo y Salazar Ugarte, Pedro, Estudios sobre la reforma electoral 2007. Hacia un nuevo modelo, México, Tribunal Electoral del Poder Judicial de la Federación, 2008, pp. 134 y ss. Al efecto, significativos resultan los "modelos" doctrinales de libertad de expresión presentados por Madrazo, quien distingue un "modelo clásico" y un "modelo democrático" y en donde parece otorgar un mayor grado de intervención legislativa al modelo democrático, de inspiración estadounidense, cuando sea necesario para "garantizar un mínimo de pluralidad y fomentar la equidad entre los interlocutores de la deliberación colectiva", mientras que al sistema clásico, de inspiración europea, le reconoce un menor grado de intervención estatal "cuando la libertad de expresión entre en tensión con la equidad (o algún otro valor de igual o mayor jerarquía)". Cfr. Madrazo, Lajous, "Libertad de expresión y equidad. La reforma electoral de 2007 ante el Tribunal Electoral”, Cuadernos de divulgación de la Justicia Electoral, México, TEPJF, núm. 5, 2001, p. 17. 
prohibición a la contratación de propaganda político-electoral; c) las restricciones al contenido de la propaganda electoral; $d$ ) las restricciones al contenido y ámbito temporal de la propaganda gubernamental; e) el régimen de sanciones frente a las infracciones cometidas en la materia; $f$ ) el reconocimiento y garantía del derecho de réplica, y $g$ ) la realización de debates entre candidatos.

Dicha intervención no se justificaría sino por la relevante función que el principio constitucional de equidad ha adquirido al interior de la función electoral de nuestro país, llevando a que el proceso interactivo de la comunicación política delimite con excesiva puntualidad el marco jurídico e institucional de la comunicación entre el ámbito político, el de los medios de comunicación y los votantes.

\section{El modelo de comunicación política no vulnera la libertad de expresión}

Aprobada la reforma constitucional-electoral de 2007 y definidos los contornos del nuevo modelo de comunicación política, iniciaron los embates y las resistencias de los medios de comunicación (principalmente la radio y televisión), los grupos empresariales, e incluso, de personajes del mundo intelectual, quienes desde distintas tribunas señalaron que el modelo vulneraba la libertad de expresión y por derivación, el derecho a la información de los ciudadanos, fundamentalmente por tres cuestiones: $a$ ) por el monopolio de la comunicación política conferido a los partidos políticos a través de los tiempos del Estado; $b$ ) por prohibir la contratación de propaganda política a los partidos políticos, y c) por prohibir similar contratación por terceros (personas físicas y morales) interesados en el acontecer político del país. ${ }^{15}$

Contrario a lo que allí se sustentó, la reforma no "vulneró" ni "atentó” contra la libertad de expresión, sino que la moduló, o para ser

15 Para contextualizar las tensiones a las que se sometió la reforma, véase Salazar Ugarte, Pedro, "La reforma constitucional. Una apuesta ambiciosa”, en Córdova Vianello, Lorenzo y Salazar Ugarte, Pedro (coords.), Estudios sobre la reforma electoral 2007..., cit., pp. 76 y ss. 
más precisos, la delimitó. ${ }^{16}$ La diferencia no es menor. No es lo mismo transgredir, quebrantar o violar un derecho fundamental que proceder a determinar sus contornos jurídicos, es decir, a fijar la extensión y los alcances que puede tener; de ahí que cuando una norma vulnera un derecho fundamental se considera inconstitucional, mientras que cuando una norma entraña una restricción a las facultades o los alcances de una libertad, la misma puede justificarse si a través de ella se protegen otros derechos, libertades, bienes, principios o fines constitucionales. ${ }^{17}$

Si quien fija esos contornos es el legislador constitucional, se pone de manifiesto la voluntad de limitar los alcances de una libertad desde la propia Constitución. Pero si es el legislador ordinario, su capacidad normativa se ve disminuida a un ejercicio de delimitación dentro de los límites que derivan de la norma fundamental.

Ni la libertad de expresión ni el derecho a la información representan derechos absolutos; como todos los demás derechos y libertades están sometidos a límites impuestos desde la Constitución, y a posteriores ejercicios de concretización legislativa y compatibilización con otros derechos y libertades. Los límites impuestos, no obstante, deben ser razonables, justificados y respetar el contenido esencial del derecho para que sea compatible con el test de proporcionalidad. ${ }^{18}$

16 En una falta de apreciación y técnica, el dictamen de la Cámara de Diputados señaló: "no se trata de imponer restricciones o limitaciones a la libertad de expresión"; aunque en estricto sentido eso fue lo que realizó la reforma. Cfr. Dictamen de las Comisiones Unidas de Puntos Constitucionales y de Gobernación de la Cámara de Diputados del 14 de septiembre de 2007, p. 5.

17 Sobre los límites a los derechos fundamentales, acúdase a Prieto Sanchís, Luis, "La limitación de los derechos fundamentales y la norma de clausura del sistema de libertades", Justicia Constitucional y Derechos Fundamentales, Madrid, Trotta, 2003, pp. 217 y ss.

18 Nuestro máximo tribunal ha sostenido en la tesis que lleva por rubro LiBERTAD DE EXPRESIÓN. LA RADIODIFUSIÓN ES UN MEDIO TECNOLÓGICO PARA EJERCER ESE DERECHO, que "las restricciones deben cumplir con los criterios de: a) razonabilidad, esto es, deberá enfocarse a los fines perseguidos, y b) proporcionalidad, que se traduce en que la medida no impida el ejercicio de aquel derecho en su totalidad o genere en la población una inhibición en su ejercicio”. Tesis 1a. XIX/2012 (9a.), Semanario Judicial de la Federación y su gaceta, Décima Época, t. 1, junio de 2012, p. 262, 1a. Sala, Libro IX. Sobre la razonabilidad y proporcionalidad, acúdase a Sánchez Gil, Rubén, "El principio de proporcionalidad en la jurisprudencia mexicana”, en Carbonell, Miguel (coord.), El principio de proporcionalidad y protección de los derechos fundamentales, México, Comisión Nacional de los Derechos Humanos-Comisión Estatal de Derechos Humanos de Aguascalientes, 2008, pp. 239 y ss. 
La Suprema Corte de Justicia ha reconocido en distintas ocasiones que la libertad de expresión tiene límites, que los mismos están tasados constitucionalmente y que el legislador cuenta con atribuciones para regular su modo de ejercicio. ${ }^{19}$ En consecuencia, las distintas modalidades en las que se exterioriza el pensamiento (de forma lingüística, simbólica o artística), los diversos medios que se emplean como plataforma de difusión (desde panfletos hasta la prensa escrita, la radio y televisión), y los contenidos comunicativos que se difunden con diversos propósitos (entrevistas, spots, debates) pueden verse sometidos a actos de delimitación para compatibilizar su contenido dentro del concierto de libertades amparadas por la Constitución.

En concordancia con lo anterior, si la libertad de expresión es una libertad fundamental para la deliberación en el contexto democrático, es evidente que puede estar sujeta a limitaciones constitucionales. De la misma manera, si la radio y la televisión representan medios tecnológicos para el ejercicio de dicha libertad, y si el acceso a los medios masivos de socialización de la información que la conforman presupone el ejercicio de una libertad de contratación de espacios, tiempos o promocionales, es indudable que tanto la actividad de los medios de comunicación como las libertades contractuales pueden ser reguladas legislativamente con el mismo propósito.

Con base en lo anterior, es necesario hacer las siguientes precisiones.

\section{En torno al monopolio de la propaganda político-electoral de los partidos políticos}

Una de las piedras angulares del nuevo modelo de comunicación se basa en la noción de "propaganda político-electoral” que alcanzó rango constitucional mediante su mención explícita en el artículo 41, y que como consecuencia de ello, adquirió una dimensión específica y un contenido puntual como mensajes "de los" partidos políticos relativos a "cuestiones de contenido político-electoral", con la intención de influir en las preferencias de los electores. ${ }^{20}$

19 Jurisprudencia 26/2007, LibertAd De EXPRESión. Sus LÍmites, Semanario Judicial de la Federación, Novena Época, t. XXV, mayo de 2007, p. 1523.

20 Astudillo, César, "El nuevo sistema..., cit., pp. 131 y ss., 149 y ss. 
La definición fue resultado de una acotación legislativa dirigida a anular las conductas que habían proliferado en la elección presidencial de 2006, en donde spots electorales de alto impacto social tuvieron su origen en un ejercicio contractual auspiciado por diversos grupos empresariales. ${ }^{21} \mathrm{Al}$ difundirse a partir de una relación mercantil con los medios de comunicación, quedó al descubierto que la capacidad económica de los agentes secundarios o indirectos del proceso electoral podía introducir, tal como ocurrió, elementos de inequidad en la contienda electoral.

Consecuentes con la idea de que la propaganda político-electoral representa una prerrogativa a favor de los partidos políticos, la reforma se constriñó a consolidar la exclusividad de estos en el acceso y difusión de propaganda con fines políticos y electorales. Eliminó, en consecuencia, la posibilidad de acceder a dicha prerrogativa a otros actores políticos y sujetos sociales.

Sin embargo, la regulación no vulneró la libertad de expresión de los ciudadanos, dado que únicamente limitó la capacidad de socializar los mensajes de contenido político que corresponden a los partidos. Los ciudadanos mantuvieron intocado el ejercicio de sus libertades de pensamiento, expresión e información, así como el acceso a los distintos medios de comunicación para poder externarlas. De ahí que no sea adecuado pretender que quien no ostenta la consideración de partido político tenga acceso a una prerrogativa que por su especial naturaleza utiliza la radio y la televisión para su difusión masiva, y que sea igualmente inexacto afirmar que los partidos políticos, sus candidatos, los periodistas, analistas o el común de los ciudadanos, tengan vedado externar sus ideas o posiciones políticas en formas y vías adicionales, como las entrevistas, los reportajes, las mesas de análisis y discusión, los debates, etcétera.

El canal de la "información" de contenido político-electoral no fue regulado en la reforma, por lo cual toda socialización de información, de ideas, pensamientos, posturas, a favor o en contra de cualquier partido político o candidato está plenamente amparada por la libertad de

${ }^{21}$ Sobre los efectos producidos por la participación de estos agentes, remitimos al Dictamen relativo al computo final de la elección de presidente constitucional de los Estados Unidos Mexicanos, Declaración de validez de la elección y de presidente electo del Tribunal Electoral del Poder Judicial de la Federación publicado en el Diario Oficial de la Federación el 8 de septiembre de 2006. 
expresión y principalmente por el derecho a informar y ser informado de las propuestas de los candidatos en época electoral. ${ }^{22}$

La única modulación existente es la que deriva del principio de equidad. Dicho postulado opera a favor de los partidos políticos y sus candidatos para auspiciar el tratamiento equitativo de los medios de comunicación en la difusión y cobertura de sus actividades de precampaña y campaña, y en el acceso a los espacios informativos a través de las diferentes modalidades ya referidas (entrevistas, reportajes, etcétera).

Respecto de los medios de información, el principio aludido ejerce su influencia en el tratamiento informativo, constriñendo a que se distinga entre las notas informativas y los comentarios, juicios de valor o alusiones que editorialicen sus contenidos, y para que confieran equidad de trato a las notas que difundan desde el punto de vista cuantitativo y cualitativo. Finalmente, para que garanticen el derecho de réplica, a fin de que cualquier información errónea tenga oportunidad de ser aclarada inmediatamente, ante los efectos negativos que puede generar en el desarrollo de la contienda electoral.

Los comunicadores y periodistas, en el marco de la libertad de expresión, están solamente obligados a conducirse con responsabilidad en el ejercicio de la crítica respetuosa y abierta hacia los precandidatos, candidatos y partidos políticos. ${ }^{23}$ Los ciudadanos, por su parte, únicamente encuentran límites a la libertad de expresión en los términos dispuestos por el artículo sexto constitucional, cuando en su ejercicio ataquen a la moral, los derechos de tercero, provoquen algún delito o perturben el orden público.

22 Así se reconoce por la Sala Superior del TEPJF, en la jurisprudencia 29/2010, 25 de agosto de 2010, pendiente de publicación, de rubro: RADIO Y TELEVISIÓN. LA AUTÉNTICA LABOR DE INFORMACIÓN NO CONTRAVIENE LA PROHIBICIÓN DE ADQUIRIR O CONTRATAR TIEMPO.

${ }^{23}$ Sobre las normas para favorecer el tratamiento equitativo en la información electoral producto de la cobertura noticiosa, acúdase al acuerdo del Consejo General del Instituto Federal Electoral mediante el que se aprueba el "Proyecto de sugerencias de lineamientos generales aplicables a los noticiarios de radio y televisión respecto de la información o difusión de las actividades de precampaña y campaña de los partidos políticos durante el proceso electoral federal 2011-2012", Acuerdo CG291/2011, del 14 de septiembre de 2011. 


\section{La prohibición de contratar propaganda a los partidos políticos}

Una de las premisas fundamentales del nuevo modelo de comunicación político-electoral consistió en eliminar el acceso oneroso de los partidos a la radio y televisión, y abrir, por otro lado, el conducto de los tiempos oficiales que corresponden al Estado, poniéndolos a disposición de los partidos a través de una forma de asignación administrada en exclusiva por el IFE. ${ }^{24}$

El derecho de acceso a los medios de comunicación bajo un esquema puntualmente definido de tiempos — de conformidad con distintos criterios, como el año electoral o no electoral, o la etapa de precampaña, intercampaña o campaña- y rangos de difusión dentro de los horarios de transmisión, posibilita la adecuada exposición de los mensajes políticos o electorales de los partidos y justifica la prohibición para que no puedan contratar o adquirir, por sí o por terceras personas, tiempos en cualquier modalidad de radio y televisión. Por un lado, se estatuye una prerrogativa al más alto nivel normativo, $\mathrm{y}$ por otro, una prohibición contundente.

Al margen de lo que pudiera pensarse, esta característica no fue producto de una ocurrencia política, ni de una invención jurídica; más bien es el resultado de la aproximación a las premisas del modelo de comunicación política de estirpe europeo, asentado en el acceso de los partidos a la radio y televisión a través de espacios "gratuitos" y en la negativa de cualquier posibilidad de contratación de publicidad electoral. El derecho comparado constata que ambas características están presentes en democracias constitucionales altamente consolidadas como en Inglaterra, España, Francia, Alemania, Suiza, e Italia, este último, es el único que permite alguna modalidad de contratación de mensajes políticos en las radiodifusoras privadas. ${ }^{25}$

En este sentido, si los partidos políticos son beneficiarios exclusivos de una prerrogativa de acceso a la radio y televisión, es incorrecto hablar de vulneración a la libertad de expresión por no permitir a los mismos sujetos políticos contar con una modalidad alternativa de acceso a medios, porque ello traería como consecuencia la sobreexposición mediática de los partidos, la reintroducción del factor oneroso

24 Jurisprudencia 29/2010, cit.

25 Astudillo, César, “El nuevo sistema..., cit., pp. 133 y ss. 
en el acceso a medios, la ruptura de la paridad de condiciones en la competencia, y el ensanchamiento de los costos en los procesos electorales. ${ }^{26}$

Por el contrario, al cerrar el acceso a estas vías de comunicación, la reforma impulsa la diversificación de las vías de difusión de las ideas y busca igualmente que los partidos utilicen otros canales y formatos de comunicación con los ciudadanos, lo cual contribuye a enriquecer el intercambio de información de contenido político.

\section{La prohibición de contratación de propaganda a personas físicas y morales}

La tercera generación de reformas electorales iniciada desde 1993 ha profundizado en la garantía de la par condicio en la competencia política; se comprende entonces por qué resultó indispensable reafirmar la "exclusividad" de los partidos para difundir propaganda política en radio y televisión como base de una prerrogativa pública, y por qué fue necesario cerrar las vías de acceso de terceros a la contratación de propaganda. ${ }^{27}$

Esta ha sido, sin duda, la limitación más impugnada por quienes demostraron su rechazo a la reforma constitucional-electoral de 2007. Paradójicamente, la norma prohibitiva existía previamente en el Cofipe, pero había sido ineficaz ante la carencia de facultades que permitieran a la autoridad electoral sancionar su contravención. ${ }^{28}$

La prohibición aludida es coherente con el resto de un diseño comunicacional fundado en el uso exclusivo de los tiempos oficiales del Estado. Si la restricción de contratar espacios se hizo con el objeto de equilibrar la competencia política, no podía dejarse abierto un flanco para permitir que por ahí discurriera nuevamente la inequidad.

Ha sido la interpretación de quienes se interesan en fracturar las bases del nuevo modelo, la que ha llevado a no tener claridad sobre el

26 Para ahondar en estas consideraciones remito a los argumentos de Carbonell, Miguel, “La libertad de expresión...”, op. cit., pp. 45 y ss.

27 Astudillo, César, "El nuevo sistema..., cit., pp. 151 y ss.

28 Recordemos que el artículo 48.1 del Cofipe señalaba: "Es derecho exclusivo de los partidos políticos contratar tiempos en radio y televisión para difundir mensajes orientados a la obtención del voto durante las campañas electorales, conforme a las normas y procedimientos que se establecen en el presente artículo" (énfasis añadido). 
ámbito específico de la limitación y su justificación. Lo que está vedado es la "contratación" de propaganda político-electoral en radio y televisión. La norma no restringe en ningún momento la posibilidad de emitir ideas, fijar posturas o externar opiniones de contenido político, ni mucho menos el empleo de las distintas vías existentes para difundirlas, incluyendo la radio y televisión. Dispone con claridad meridiana que no es posible contratar espacios para difundir comunicaciones de contenido político, pero permite socializarlas si no hay un acto de adquisición o contratación de por medio.

Es evidente que la libertad para exteriorizar puntos de vista tiene vinculación con la capacidad de emplear distintos medios para su difusión. Lo que no es aceptable es señalar la vulneración de la libertad de expresión si el ejercicio de ésta no viene potenciado a través del acceso a aquellos medios de comunicación que permitan la mayor "circulación" de los mensajes o que generen la más amplia influencia en los ciudadanos.

El contraste se encuentra en la nula diferenciación entre "libertad de expresión" y "libertad de contratar y difundir propaganda". La primera representa una actividad intelectual, espontánea o planificada, que no necesita de mayores artilugios para concretarse y que puede emplear distintas vías para su difusión; es una comunicación con una clara dimensión social que coadyuva a generar una opinión pública que indudablemente habrá de proyectarse en el debate social, y que se articula a partir del libre acceso a los medios de comunicación, dentro de la dialéctica de la información; la segunda, en cambio, es una actividad planificada unilateralmente en función de un objetivo político, presupone el concurso de los medios de comunicación, particularmente la radio y televisión, ostenta una efectividad político-electoral que se proyecta directa e inmediatamente sobre las elecciones, y se ancla en un acceso a los medios de carácter mercantil, dentro de la lógica del interés partidista.

Lo anterior lleva a concluir que cuando se restringe la contratación de mensajes cuyo contenido les confiere el carácter de "propaganda político-electoral”, no se está vulnerando la actividad intelectual que permite externar libremente lo que se piensa de un candidato, de su partido, de sus ideas o programas políticos, ni tampoco se está coartando su difusión en el ámbito público, en el que de forma natural entran en competencia y confrontación con posturas contrarias. Lo que en realidad se está limitando es la mercantilización de los pro- 
ductos del pensamiento y la posibilidad de que unos se sobrepongan a otros por tener entrada a un "espacio público" distinto, cuyo acceso se encuentra condicionado por el pago de una prestación monetaria. ${ }^{29}$

No existe, en consecuencia, vulneración alguna de la libertad de expresión. Hay, más bien, una razonable restricción a la libertad de contratación que como sabemos, se encuentra vinculada a la autonomía de la voluntad de las personas. Dicho de forma sintética, la norma no restringe la "formación" y la "expresión" de las ideas, pero sí prohíbe, y además de manera contundente, el "mercado" de las ideas. Si ello ocurre desde el ángulo de las personas, también sucede desde la perspectiva de los medios de comunicación. La restricción no vulnera las libertades constitucionales de expresión e información, ni la libertad comercial de los concesionarios, como lo ha subrayado la Sala Superior del TEPJF, ya que se entienden como limitaciones válidas y justificadas dentro de un contexto que tiene en la equidad uno de sus principios a salvaguardar. ${ }^{30}$

Como última cuestión a discernir se encuentra el hecho de que sólo está vedada la contratación de propaganda político-electoral, por lo que toda comunicación que no se dirija a influir directamente en las preferencias electorales de los ciudadanos, ni se pronuncie a favor o en contra de los partidos y sus candidatos, se encuentra al margen de la restricción. Consecuentemente, sí es posible contratar mensajes de contenido político dirigidos a elevar la calidad del debate, a fijar la posición respecto a temas de relevancia pública, a manifestarse a favor o en contra de determinada decisión o política, siempre y cuando su formato, contenido, periodo y forma de difusión no tenga propósitos electorales. ${ }^{31}$

29 La noción del "mercado de las ideas" nace con el conocido voto disidente del juez Oliver W. Olmes en el caso Abrams vs US 250 US 616 de 1919. Sobre el contenido del mismo véase Beltrán de Felipe, Miguel y González García, Julio V., Las sentencias básicas del Tribunal Supremo de los Estados Unidos de América, 2a. ed., Madrid, Centro de Estudios Políticos y Constitucionales, Boletín Oficial del Estado, 2006, pp. 200 y ss.

30 Jurisprudencia 30/2009, RAdio y TELEVISIÓN. LA PROHIBICIÓN DE CONTRATAR PROPAGANDA ELECTORAL NO TRANSGREDE LAS LIBERTADES CONSTITUCIONALES DE LOS CONCESIONARIOS, Gaceta de jurisprudencia y tesis en materia electoral, TEPJF, año 3, núm. 5, 2010, pp. 45 y ss.

31 Al respecto, $c f r$. Salazar Ugarte, Pedro, "La libertad limitada”, Nexos, núm. 366, junio de 2008, pp. 8-10. También, Carbonell, “La libertad de expresión..., cit., pp. 49 y ss. 


\section{Deficiencias institucionales que no favorecen la fluidez de la libertad de expresión en su manifestación político-electoral}

Dado que el objetivo del modelo de comunicación político-electoral es favorecer el intercambio libre y plural de ideas dentro del espacio público, provenientes de las instituciones gubernamentales, electorales, partidos políticos, candidatos y el conjunto de ciudadanos bajo el apoyo de la intermediación de los medios de comunicación, es necesario apuntar aquellas deficiencias del diseño institucional que no favorecen una mayor fluidez en la manifestación de las ideas ni su oportuna socialización en el ámbito electoral.

\section{La predeterminación de un formato único. La carencia de alternativas a una comunicación fluida}

La comunicación político-electoral puede adquirir diversos formatos y contenidos; unos permiten una mayor fluidez y un más profundo contenido informativo como los debates, las entrevistas y conferencias de prensa, mientras que otros se dirigen a enviar breves mensajes y propuestas - como los spots y la publicidad electoral- bajo una construcción persuasiva que une la dimensión verbal con la visual, pero que por su brevedad y unilateralidad, en tanto pensados y diseñados exclusivamente por los partidos políticos, disminuyen la riqueza de su contenido.

Durante el proceso de gestación de la reforma que introdujo el nuevo modelo de comunicación político-electoral, los senadores de la República parece que tuvieron un diagnóstico claro sobre los efectos de auspiciar un formato único para la comunicación político-electoral basado en el spot, y sobre la penetración del marketing político en nuestro sistema electoral, al destacar:

Las campañas electorales han derivado en competencias propagandísticas dominadas por patrones de comunicación que les son ajenos, en los que dominan los llamados "spots" de corta duración, en que los candidatos son presentados como mercancías y los ciudadanos son reducidos a la 
función de consumidores. Se trata de una tendencia que banaliza la política, deteriora la democracia y desalienta la participación ciudadana... ${ }^{32}$

A pesar de ello, y por paradójico que parezca, el modelo finalmente aprobado se basó fundamentalmente en el formato criticado por los senadores. Al hacer de éste el eje articulador del modelo, en lugar de afrontar los efectos nocivos de dicho formato prácticamente lo institucionalizaron y potenciaron sus efectos. Por ello, no es casual que José Woldenberg haya señalado que la llamada "spotización" constituyó una "derivación perversa" del nuevo modelo de acceso a la radio y televisión. ${ }^{33}$

La totalidad del tiempo que el Estado confiere a los partidos políticos y las instituciones electorales, en vez de ser adecuadamente utilizado dentro de un abanico de formatos para la comunicación quedó drásticamente reducido a un formato casi único que terminó por repartirlo en spots de breve duración. En la decisión de privilegiar la fluidez o la predeterminación del contenido de los mensajes políticos, el legislador optó por esta última posibilidad. Dentro de las campañas, los spots electorales e institucionales quedaron prefigurados en la ley con una duración de 30 segundos; ${ }^{34}$ en periodo no electoral fue de 20 segundos para los partidos políticos, y de 30 segundos para las instituciones electorales, agregándose un programa mensual de 5 minutos por partido. ${ }^{35}$

En un entorno altamente mediatizado como el de nuestros días, es significativo subrayar que el formato del spot cumple con algunas exigencias de la comunicación política. En efecto, a los partidos políticos les interesa posicionar un mensaje fácilmente comprensible o una ima-

32 Dictamen de las Comisiones Unidas de Puntos Constitucionales; de Gobernación; de Radio, Televisión y Cinematografía; y de Estudios Legislativos de la Cámara de Senadores del 11 de septiembre, pp. 16-21.

33 Woldenberg, José, Comunicación politica, medios y elecciones, México, AMEDI, 2011.

34 En el artículo 56.4 del Cofipe se permite que los mensajes electorales tengan una duración de 30 segundos, uno y dos minutos. El artículo 14.1 del Reglamento de radio y televisión en materia electoral, confirma lo anterior y dispone que corresponderá al Comité de radio y televisión aprobar la duración de los promocionales de los partidos políticos y hecho lo anterior, todos deberán sujetarse a la misma unidad de medida.

35 Artículo 9.1 del Reglamento de radio y televisión en materia electoral, véase Instituto Federal Electoral, Administración del tiempo..., cit., pp. 51 y ss. 
gen claramente identificable (construcción del contenido) a la mayor cantidad de personas posibles (mayor auditorio), de manera rápida o coyuntural, con sentido de la oportunidad política (beneficio), lo cual propicia que el formato aludido presente múltiples ventajas. ${ }^{36}$ Acaso por ello, la necesidad de nuevas formas de comunicación dentro de una sociedad masificada y altamente mediatizada ha ido deslizando la construcción del un mensaje político-electoral a través de las técnicas del marketing publicitario. ${ }^{37}$

La aplicación de métodos de estudio de mercado y de técnicas de publicidad comercial a las campañas ha irrumpido con fuerza con el objetivo de "posicionar" un producto - es decir una idea, propuesta, promesa, crítica o imagen política-, en función de un tipo de "mercado" - esto es, del grupo de ciudadanos a los que se dirige - con la finalidad de persuadirlo para votar a favor o en contra de una opción política determinada. ${ }^{38}$ No obstante, la extrema brevedad del mensaje únicamente permite posicionar una idea, una propuesta, una crítica, sin que el formato permita elementos de contexto o de contraste que ayuden al ciudadano discernir con mayores elementos la bondad de la idea, la idoneidad de la propuesta o la solidez de la crítica.

El uso del spot ha banalizado la política al convertir a los candidatos en mercancías y a los ciudadanos en clientes. El mensaje y la imagen proyectada no corresponden con la realidad política y social y no compromete a sus emisores y destinarios con la discusión reflexiva de fondo, ni con la agenda de los problemas públicos y mucho menos con las alternativas de solución.

El formato elegido por el legislador y la unidad de medida reglamentada en su oportunidad por el Consejo General y aprobada por el Comité de Radio y Televisión del IFE, han limitado las potencialidades de la comunicación política e institucional al preferir píldoras de

36 Sobre los tipos, las funciones y los contenidos de los anuncios políticos televisivos, véase García Beaudoux et. al., Comunicación política..., cit., pp. 44 y ss.

37 En torno al marketing político y su influencia en las campañas electorales, véase Herreros, Arconada, Mario, Teoría y técnica de la propaganda electoral (formas publicitarias), Barcelona, Promociones y publicaciones universitarias, 1989, pp. 157 y ss.

38 Sobre las técnicas de construcción de los mensajes políticos véase: Barranco Saiz, Francisco, Marketing político y electoral, Madrid, ESIC, 2010, pp. 37 y ss.; Martínez Pandiani, Gustavo, Marketing político. Campañas, medios y estrategias electorales, Buenos Aires, Urgeman editor, 2008, pp. 121 y ss.; Maarek, Philippe J., Marketing político y comunicación, España, Paidós, 2008, pp. 41 y ss.; Martín Salgado, Lourdes, Marketing político, España, Paidós, 2002, pp. 45 y ss. 
20 y 30 segundos, de escaso valor informativo sobre modalidades que auspician un flujo más libre y flexible de información político-electoral, de ideas, posturas, críticas, posiciones y propuestas políticas. ${ }^{39}$ La decisión, ha impedido que la comunicación institucional, aquella dispuesta en favor de las autoridades electorales, ${ }^{40}$ pueda adquirir un mayor contenido informativo no sólo para explicar la propia función, o para llamar a los ciudadanos a ejercer su sufragio, sino para revelar elementos clave del proceso electoral que por no ser adecuadamente entendidos por la sociedad abonan a la percepción de una organización electoral parcial, dependiente, subjetiva y que busca salvaguardar intereses políticos determinados.

Los programas mensuales de cinco minutos a que tienen derecho los partidos políticos durante el periodo no electoral, representan un formato distinto en virtud de su duración. El contenido político del mismo es similar al que comprende la emisión consecutiva de 15 spots de 20 segundos, lo cual permite que cada partido exponga ante el auditorio su posición o ideario político a través de propuestas específicas debidamente contextualizadas. Sin embargo, la transmisión de los programas al margen de los procesos comiciales conduce a que la información política que se transmite al ciudadano no genere necesariamente una influencia electoral; además, el horario en el que se transmiten termina por limitar la capacidad de influencia que pudieran tener, lo cual redunda en que los partidos dejen de poner la atención en su producción y contenido, volviéndolos poco atractivos para el ciudadano.

Como formato adicional para la comunicación político-electoral, la reforma constitucional-electoral de 2007 incorporó la obligación de coordinar la realización de dos "debates" entre los aspirantes presidenciales. La incorporación de esta modalidad representa un ejercicio de maximización de la libertad de expresión en el contexto del debate po-

39 Véase artículo 14.1 del Reglamento de radio y TV del IFE, reformado por Acuerdo CG353/2011, de 3 de noviembre. El uso de un esquema más flexible y la conveniencia de que el IFE utilice el formato de uno y hasta dos minutos, es una sugerencia, entre otros, de la misión de expertos electorales de la Unión Europea sobre las elecciones generales del 1o. de julio de 2012. Véase EU Election Expert Mission Mexico, Informe Final, México, Elecciones Generales 1 de Julio 2012, p. 3.

40 El formato de estos promocionales es decidido por la Junta General Ejecutiva a partir de formatos de 20 o 30 segundos. Según el artículo 14.2 del Reglamento de Radio y Televisión del IFE, hecho lo anterior, todos los promocionales deberán ajustarse a una sola unidad de medida. 
lítico del todo necesario para la formación de la opinión pública y la consolidación de una sociedad democrática. El formato de los debates permite que los candidatos puedan difundir sus ideas, propuestas y programas políticos en un contexto deliberativo que fomenta el intercambio y la confrontación de opiniones y puntos de vista, la crítica de las mismas y el contraste entre candidatos. Representan, por tanto, una valiosa fuente de información política, que por el momento en el que se difunden, adquieren una relevancia fundamental para que el ciudadano decida el sentido de su voto de manera más informada.

Si bien la organización de dos debates es positiva, debe destacarse que la facultad del IFE de "coordinar" su realización, de la mano del influjo que tienen los representantes de los partidos políticos y sus candidatos para la determinación de los lineamientos, criterios y bases a los que habrán de sujetarse, han terminado por modular la riqueza de estos ejercicios comunicativos y por anteponer la rigidez y solemnidad del formato elegido ante la dificultad de armonizar las diferentes estrategias e intereses políticos de los contendientes. ${ }^{41}$

Adicional a lo anterior, la influencia social de los debates ha quedado condicionada por la propia regulación, ya que el Cofipe establece la obligación de transmitir los debates en vivo y de forma ininterrumpida para los permisionarios públicos, pero ha dejado a la discrecionalidad de los concesionarios - que paradójicamente son los que tienen mayor cobertura y capacidad de influencia- la decisión de su transmisión, sin que existen suficientes incentivos institucionales para comprometerlos a la difusión de este ejercicio democrático. ${ }^{42}$

No obstante, es de destacarse la voluntad del IFE manifestada en sus normas reglamentarias para coadyuvar en la organización de debates entre candidatos presidenciales y candidatos al cargo de senadores y diputados federales, bajo el convencimiento de que estos ejercicios constituyen manifestaciones directas de la libertad de expresión y el

${ }^{41}$ En el proceso electoral de 2012, estos lineamientos se diseñaron en una Comisión temporal del IFE, en la que, derivado de numeral sexto, se garantiza la participación de los representantes de los candidatos presidenciales, así como de un grupo de ciudadanos y especialistas acreditados en comunicación política. Véase Acuerdo del Consejo General CG14/2012, de 25 de enero de 2012.

${ }^{42}$ El artículo 70.4 del Cofipe dispone solamente que "las estaciones y canales que decidan transmitir, en vivo, los debates a que se refiere el presente artículo, quedan autorizadas a suspender, durante el tiempo correspondiente, la transmisión de los mensajes que correspondan a los partidos políticos y a las autoridades electorales". 
derecho a la información, y representan un instrumento de amplia vocación democrática. ${ }^{43}$

De conformidad con lo expuesto, parece necesario repensar el formato "casi único" prefigurado por el modelo de comunicación político-electoral en la reforma de 2007. La ausencia del factor oneroso en el acceso a la radio y la televisión o la dificultad de ordenar promocionales de más amplia duración, derivado de la "necesidad" de compatibilizarlos con la brevedad de los formatos de la propaganda comercial, no representa una justificación suficiente para mantener la carencia del valor informativo para el electorado.

$\mathrm{Al}$ respecto, se deben madurar formatos que posibiliten una comunicación más fluida con la intención de enriquecer la calidad de la competencia política, que doten de mayor dinamismo y oportunidad política al desarrollo de las campañas, aproximen un mayor volumen de información al ciudadano y mantengan la atención del electorado en un contexto en el que la constante repetición de dichos mensajes en la dinámica de la campaña produce una saturación audiovisual que en el corto y mediano plazo, puede generar repercusiones negativas. ${ }^{44}$

Lo mismo puede decirse en torno a los debates; mientras no se otorguen plenas atribuciones al IFE para que ejerza como autoridad rectora de los debates, la riqueza que subyace a los mismos será permanentemente atemperada por el juego de intereses que la lógica y el momento de la campaña determinen.

\section{La rigidez de la regulación. La ausencia de la flexibilidad necesaria}

Derivado del giro copernicano en el acceso de los partidos políticos y las instituciones electorales a los medios de comunicación, particularmente la radio y la televisión, se produjo una incisiva intervención legislativa que dio como resultado la "constitucionalización" del modelo de comunicación político-electoral con consecuencias muy

${ }^{43}$ Los lineamientos al respecto se encuentran en el Acuerdo del Consejo General CG99/2012, de 29 de febrero de 2012.

44 Juárez Gámiz, Julio, "Informar o persuadir: la centralidad del contenido mediático de la nueva ley electoral”, en Ackerman, John M. (coord.), Nuevos escenarios del derecho electoral: los retos de la reforma de 2007-2008, México, UNAM, Instituto de Investigaciones Jurídicas, 2009, p. 162. 
particulares para la permanencia, estabilidad e, incluso, aceptabilidad del modelo, pero también para su extrema rigidez y la dificultad de su cambio, acomodo y adaptación.

La constitucionalización aludida se hizo cargo de establecer las premisas en las que se asienta la arquitectura jurídica del mismo, ${ }^{45}$ pero fue más allá y reguló cuestiones como el tiempo que en año electoral queda a disposición del IFE en cada estación de radio y televisión para que sea distribuido durante las precampañas, intercampañas y campañas electorales; el tiempo correspondiente en año no electoral; la distribución del mismo en las horas de transmisión; el margen de horario en la programación en la que deben transmitirse los promocionales; las modalidades de su distribución entre los partidos políticos; aquél que corresponde a los partidos que no tengan representación en el Congreso; el tiempo que puede utilizar para fines propios o de otras autoridades electorales; la manera de asignar los tiempos en los procesos electorales locales con jornadas comiciales que coincidan con la federal y las modalidades para aquellas que no coincidan; así como su distribución entre los partidos políticos locales. ${ }^{46}$

La cobertura constitucional de estas reglas que evidentemente carecen de la relevancia para ubicarse en tan privilegiado espacio normativo, sólo es explicable como un acto de blindaje y de redefinición de la relación entre los poderes del Estado y los poderes mediáticos. En efecto, quienes impulsaron la reforma sabían que la única manera de blindar la viabilidad de futuro del modelo frente a los inminentes embates de los medios de comunicación, sus principales objetores, era elevar la regulación a rango de ley suprema. La intensidad con la que la reforma trastocó sus intereses al hacerlos perder los recursos de las campañas electorales — dada la nueva modalidad de acceso gratuitoy la forma en que disminuyó su influencia hacia la clase política —derivado de la imposibilidad de negociar las modalidades y los precios de acceso de los partidos y sus candidatos a los medios de comunicación- requerían un especial ámbito de resguardo que fuera capaz de resistir los embates a su contenido. ${ }^{47}$

45 Sobre estas premisas, a las que ya hemos hecho mención en este texto, acúdase a Astudillo, César, "El nuevo sistema..., cit., pp. 131 y ss. Del mismo autor, "Una reforma electoral a favor del ciudadano”, Revista Este País, núm. 253, mayo de 2012, p. 27.

46 Artículo 41, fracción II, de la CPEUM.

47 Woldenberg, José, “Estampas de la reforma”, cit., p. 38. 
La reforma encarnó una verdadera apuesta por redefinir el esquema de relaciones entre los poderes formales y los mediáticos "que en los años recientes había degenerado a condiciones realmente insostenibles que llegaron a evidenciar una capacidad de sujeción y condicionamiento de las instituciones públicas por parte de los intereses privados de los titulares de las concesiones" ${ }^{48}$ En este contexto, no se necesita ser muy perspicaz para advertir que la Constitución representaba el mejor pedestal para enviar un mensaje claro y contundente de reivindicación de los espacios políticos perdidos por la representación popular, convirtiéndose en el entorno propicio para afirmar la supremacía de la representación política sobre el poder de las grandes compañías de radio y televisión. ${ }^{49}$

Por ello, frente a la eventual rebeldía en el cumplimiento del pautado ordenado por la autoridad electoral, la propia reforma confirió atribuciones de verificación de la transmisión de las pautas, lo que condujo a que el IFE adquiriera una "vasta estructura tecnológica" para que a través de ciento cincuenta centros de monitoreo se cubrieran las localidades de todo el territorio nacional y se constatara el cumplimiento de las reglas del modelo por parte de los medios de comunicación. ${ }^{50}$

Todo lo anterior dio como resultado la apertura de una pesada base III en el artículo 41 constitucional, que como ya se ha afirmado estableció una regulación exhaustiva de los tiempos a asignar "al margen del proceso electoral" y "con motivo del proceso electoral" tanto a nivel federal como en el de las entidades federativas.

El esquema de distribución puede sintetizarse de la siguiente manera: en año no electoral quedan a disposición de la autoridad electoral 7 minutos y 48 segundos en cada estación radio, y 5 minutos 45 segundos en cada canal de televisión (lo que integra el 12\% del tiempo que corresponde al Estado). En radio, 4 minutos se reparten entre los par-

48 Lorenzo Córdova, "Las razones y el sentido de la reforma”, en Cordova Vianello, Lorenzo y Salazar Ugarte, Pedro (coords.), Estudios sobre la reforma electoral 2007..., cit., p. 49.

49 Recordemos que, como ha sostenido Carpizo, los medios de comunicación representan un verdadero poder. Por ello, había que atajarlo con otro gran poder, en este caso, el poder de la Constitución. Al respecto, Carpizo, Jorge, "El poder: su naturaleza, su tipología y los medios de comunicación masiva”, en Carpizo Jorge, Nuevos estudios constitucionales, México, Porrúa-UNAM, 2000, p. 344.

50 Valdés Zurita, Leonardo, "El funcionamiento del nuevo modelo de comunicación política del instituto Federal electoral. El porqué de la reforma y sus logros", ponencia dictada en la Séptima reunión Interamericana de Autoridades Electorales, p. 9. 
tidos políticos y 3 minutos 48 segundos entre las instituciones electorales del ámbito federal y estatal. En televisión, 3 minutos se asignan a los partidos y 2 minutos 45 segundos a las autoridades electorales.

Dentro del proceso electoral se ponen a disposición de la autoridad electoral un total de 48 minutos en cada estación de radio y televisión, asignados de conformidad con la etapa de la competencia electoral. En la precampaña se asignan a los partidos 18 minutos en cada estación, lo que permite la asignación de un minuto de transmisión de mensajes por cada hora, puesto que la franja de transmisiones comprende 18 horas al día, de las 6:00 a las 24:00 horas. A las autoridades electores les corresponden los 30 minutos restantes en cada estación. La etapa de intercampaña transfiere la totalidad del tiempo a las instituciones electorales con la finalidad de avanzar en la promoción del voto. En cambio, la etapa de campaña destina el $85 \%$ del tiempo a los partidos al asignarles 41 minutos en cada estación de radio y televisión, mientras que a las autoridades electorales se les asignan 7 minutos. ${ }^{51}$

Los tiempos en cada uno de los medios de comunicación aludidos se distribuyen de la misma manera que el financiamiento público; $30 \%$ de forma igualitaria y $70 \%$ de forma proporcional a la votación obtenida por cada partido político en la última elección para diputados federales.

La regulación que acaba de señalarse se encuentra estipulada ni más ni menos que a nivel constitucional lo cual, a pesar del beneficio positivo de conseguir estabilizar en el máximo nivel normativo un modelo de comunicación fuertemente contestado, ha producido una "rígida regulación" basada además en la elección original de un reducido número de "formatos" para la comunicación político-electoral.

Resultado de lo anterior, el tiempo que el IFE debe administrar está escrupulosamente determinado de conformidad con criterios como el "periodo", la "duración", el "formato", los "sujetos beneficiarios", el "ámbito de difusión”, lo cual aparta el modelo de la flexibilidad necesaria para utilizar los tiempos de Estado en esquemas menos rígidos y con mayor capacidad de adaptación a las distintas necesidades de la comunicación política.

En este sentido, es necesario reflexionar sobre la manera de introducir esquemas de flexibilización sin perder el blindaje constitucional que hoy caracteriza al modelo. Al efecto, debe esbozarse la posibilidad de

51 Instituto Federal Electoral, Administración del tiempo del Estado..., cit., p. 49. 
un uso menos rígido de los tiempos del Estado para escapar de la tiranía del spot. La alta concentración de medios de comunicación en pocas manos puede ser un elemento a favor de la posibilidad de acumular los tiempos y de transferirlos entre estaciones pertenecientes al mismo concesionario con el objeto de compactarlos en mensajes de mayor profundidad que puedan ser difundidos en las estaciones de mayor arraigo y penetración social.

La compactación de tiempos en periodo no electoral permitiría, por ejemplo, conjuntar los cinco minutos de duración del programa mensual que corresponde a cada partido en un formato distinto, como el debate, más propicio para contrastar las posturas de los partidos en función de ejes temáticos previamente definidos. La propuesta, no obstante, no es de fácil implementación, pues contrasta con el formato de la publicidad comercial adoptado por la radio y la televisión. Por lo tanto no es difícil suponer que existirá un rechazo inicial a la propuesta por las consecuencias que un formato de larga duración traería para la venta y difusión de dicha publicidad. Una forma de obligar a la apertura de estos formatos derivaría de su incorporación al texto constitucional, es decir, de dar la más privilegiada ubicación normativa, pero también la más alta rigidez a esta modalidad, lo cual, paradójicamente, es contrario a la premisa sustentada en este texto, pero constituye el típico ejemplo que vislumbra las implicaciones de haber constitucionalizado el modelo.

\section{La unidireccionalidad del modelo.}

El ciudadano como sujeto pasivo del proceso comunicativo

La comunicación política presupone, como se señaló en la definición inicial, el intercambio de información entre la clase política y el ciudadano-elector. En un entorno de deliberación pública como el que exige una sociedad democrática, el vínculo entre ambos actores no debe concebirse como una relación rígida y unidireccional de emisor a receptor, sino como una relación abierta que permita una recíproca retroalimentación.

La comunicación política es en esencia bidireccional, derivado de su capacidad para abrir canales a la interacción directa entre los sujetos participantes. Si bien es cierto esta cualidad no está siempre presente cuando la comunicación pasa a través de los medios clásicos de 
difusión, como la radio y la televisión, importante es advertir que la irrupción de las plataformas de Internet y de las redes sociales han venido a cambiar el rostro de los usos comunicativos, obligando a todos los medios de difusión a ajustarse a nuevas modalidades caracterizadas por la apertura de vínculos dialécticos entre sus participantes.

La novedad más importante que ha traído consigo la revolución tecnológica de nuestros días consiste precisamente en el alejamiento de la comunicación política vertical y en la superación de la interacción política intermitente, cuyos espacios deliberativos, de decisión y participación electoral son sumamente reducidos, altamente segregados y con escazas posibilidades para el ciudadano. ${ }^{52}$

El fenómeno descrito se proyecta hacia varias dimensiones del proceso comunicativo entre las que destaca, por su relevancia, la modificación del rostro de las campañas políticas. De una modalidad de campaña eminentemente contemplativa, en donde el ciudadano se reducía al papel de receptor de los mensajes políticos, se ha venido mudando a campañas "replicantes" o "interpelativas" en las que el ciudadano se erige como centro de mensajes y demandas directas a los candidatos, y en el cual los medios pierden cada vez más su capacidad de servir como agentes de intermediación, filtro y encauzamiento de las vías de acceso al conocimiento de los asuntos públicos. ${ }^{53}$

La nueva modalidad de campaña dentro de un esquema de comunicación horizontal dota al ciudadano de herramientas eficaces para incorporarlo a un marco de influencia política a partir de la información que logra socializar; le brinda interacción con la representación política, los partidos y los candidatos; le confiere iniciativa para presentar propuestas y vincularse con otros ciudadanos interesados en la política; capacidad de movilización con fines políticos (a favor de políticas) o electorales (de partidos y candidatos); le otorga la posibilidad efectiva de reclamar en tiempo real y con capacidad de reacción inmediata, y es una vía privilegiada para hacer llegar su voz a un número muy amplio de ciudadanos anónimos, desvinculados en lo personal, pero vinculados por ese ánimo colectivo de no ser sujetos

52 En términos generales, acúdase a Rodóta, Stefano, Tecnopolitica. La democrazia e le nueve tecnologie della comunicazione, Roma, Laterza, 1997.

53 En torno a las características de este tipo de comunicación, campaña e, incluso, de la "democracia replicante", acúdase a Dader, José Luis, "La ciberdemocracia posible. Reflexión prospectiva a partir de la experiencia en España”, CIC Cuadernos de Información y Comunicación, núm. 6, 2001, Madrid, UCM, pp. 178 y ss. 
pasivos de una relación comunicativa, sino productores directos de información, mensajes, demandas y reclamos de naturaleza política. Esta transformación, en opinión de Dader, puede llevar a un cambio trascendental en la concepción actual de la democracia, hasta hacerla una democracia replicante e interpelativa fundada en ciudadanos que participen activamente en la toma de las decisiones colectivamente vinculantes. ${ }^{54}$

El modelo instaurado en la reforma constitucional-electoral de 2007, basado preponderantemente en el formato del spot, sigue anclado en una visión vertical de comunicación político-electoral. El rasgo unidireccional que introduce, al estar concebido para una plataforma de mensajes de contenido breve, carente de verdadera información para el ciudadano, y con una construcción desde la lógica del marketing político, lejos está de alentar la deliberación en el entorno de la competencia política, ni la réplica en el ámbito de las ideas, propuestas o compromisos que allí se generan.

El modelo, en consecuencia, no favorece un proceso comunicativo abierto, fluido y dialéctico, ni la instauración de campañas deliberativas o replicantes, mucho menos flexibles y espontáneas en donde la difusión de sus mensajes puedan ser ajustados mediante criterios de oportunidad política.

De cara a la reforma del modelo es necesario replantear esta premisa para generar un modelo de comunicación político-electoral más horizontal, en donde el ciudadano se considere no solamente receptor, sino agente activo del proceso comunicativo, con capacidad para generar información, debatir, replicar y participar decididamente en la deliberación política, y movilizarse al interior de las campañas electorales.

\section{La incompletitud del modelo. La omisión de sujetos que deben tener voz en el proceso comunicativo}

Todo modelo de comunicación político-electoral necesita dar voz a los distintos sujetos del sistema político, sean estos los poderes públicos, los partidos políticos o los ciudadanos. De esta manera, uno de sus objetivos debe ser garantizar que quienes participan en el espacio

54 Idem. 
deliberativo tengan condiciones razonablemente equitativas de hacer llegar sus mensajes hacia el ciudadano-elector. Lo anterior es particularmente importante a la hora de dar voz a los partidos políticos, sujetos privilegiados de la lucha por el poder, pero debe serlo también si el sistema electoral reconoce a otros actores y competidores por la representación popular.

Con motivo de la reforma política de agosto de 2012, y la incorporación de las candidaturas independientes al sistema constitucional mexicano, el modelo de comunicación político-electoral prefigurado desde la Constitución, demostró uno más de sus inconvenientes actuales: su falta de integralidad. En efecto, no fue reformado para permitir que los ciudadanos postulados en ejercicio de sus derechos de participación política, sin el auspicio de partido político alguno, tuvieran acceso a los tiempos del Estado en la radio y la televisión, por lo que se mantiene rígidamente asentado en el monopolio de la participación política de los partidos, generando un rasgo de exclusión que debe ser puntualmente atendido para incorporar esta nueva modalidad de mensajes al circuito de la comunicación política.

Lo apenas señalado incorpora un profundo sentido de inequidad al afectar la paridad de condiciones en la competencia política por la desventaja que infiere a los candidatos independientes frente a los partidos políticos, en detrimento de la socialización de información de todos los sujetos políticamente relevantes, en clara contravención del derecho fundamental de acceder en condiciones generales de igualdad a las funciones públicas del país, tal y como lo reconocen los artículos 23 de la Convención Americana sobre Derechos Humanos, 25 del Pacto Internacional de Derechos Civiles y Políticos, y el principio de equidad, pilar fundamental de la función electoral establecido en el artículo 41 constitucional.

Al respecto cabe cuestionarse si la ausencia de reforma al precepto apenas aludido debe entenderse como una decisión directa del órgano reformador de la Constitución dirigida a cerrar esta vía comunicativa a quienes compitan bajo la modalidad de las candidaturas independientes o si, por el contrario, fue producto de una reforma parcial, omisa y carente de integralidad como las que muchas veces acontecen en nuestro sistema jurídico.

El modelo contiene hoy en día una omisión de relevancia. Mientras impida el flujo de información de contenido político entre todos los 
actores relevantes del escenario público no podrá considerarse integral, abierto, plural y omnicomprensivo.

\section{La ausencia del sentido de igualdad. La discriminación en los criterios de distribución}

Un modelo de comunicación político-electoral asentado en la máxima de la equidad está obligado a otorgar posibilidades de difusión de mensajes de contenido político razonablemente proporcionales a todos quienes compiten por el sufragio ciudadano. Privilegiar las voces de unos en detrimento de otros, abrir canales de comunicación exclusivamente a ciertos sujetos y cerrárselos a otros, o discriminar el acceso a medios de comunicación bajo la premisa de que ciertos cargos o mensajes son más relevantes que otros, constituyen decisiones que pueden justificarse bajo ciertas condiciones, pero que en determinados contextos resultan altamente negativas y reprochables.

La distribución de los tiempos de Estado en radio y televisión actualmente vigente confiere características de inequidad al modelo de comunicación político-electoral en tanto realiza la distribución de espacios diferenciados bajo el criterio del "tipo de elección" federal o estatal de que se trate.

En las elecciones estatales coincidentes con la elección federal, el IFE distribuye 18 minutos en cada estación de radio y televisión entre los partidos políticos para la emisión de propaganda de precampaña, de los cuales 11 minutos se destinan a las precampañas federales y 7 minutos se dedican a las precampañas estatales. Para la emisión de propaganda de campaña, el IFE distribuye 41 minutos, de los cuales 26 minutos se destinan a las campañas federales y 15 minutos se dedican a las precampañas estatales.

En elecciones que se desarrollan únicamente en las entidades federativas, el criterio de inequidad se produce por el tiempo que se distribuye entre los partidos políticos durante el periodo de campaña electoral, ya que asciende solamente a 18 minutos en cada estación de radio y televisión, mientras que las instituciones electorales cuentan con 30 minutos de tiempo.

Los anteriores criterios de distribución carecen de una explicación que coadyuve a justificarlos. En un entorno democrático el ciudadano debe contar con iguales oportunidades de recibir información, tan- 
to de las elecciones federales como de las estatales, porque en ambos casos necesita estar en condiciones de ejercer el voto de manera informada y razonada. Sin embargo, parece que dicho esquema se guió por elementos cualitativos y no cuantitativos. Son muchos más los puestos de representación popular que se eligen en el ámbito de los estados y el Distrito Federal, que los de la federación. Sin embargo, la presidencial es la elección de mayor significación política y como tal suele acaparar un mayor grado de atención mediática que encuentra su correspondiente en las normas del modelo que otorgan mayores tiempos a las campañas federales.

El número de cargos de elección popular en los estados de la República, así como la reciente reforma a favor de las candidaturas independientes obliga a tener en cuenta el criterio cualitativo en la redefinición de tiempos entre las campañas federales y estatales. Lo apenas señalado conduce a reflexionar en el establecimiento de medidas de compensación que equilibren el tiempo en radio y televisión que se destina a las campañas estatales, sobre todo ante la expectativa de que, derivado de naturaleza, es muy probable que sea en este ámbito en donde se produzca una mayor participación de candidaturas independientes.

Igual inequidad subsiste en las elecciones estatales no coincidentes con la federal, en donde paradójicamente es más el tiempo que se dispensa a favor de los árbitros que el que se distribuye entre los competidores.

Algo similar puede afirmarse en relación con el tiempo que se asigna a las instituciones electorales, quienes deben tener igual oportunidad de convocar a la ciudadanía a ejercer el voto en la jornada electoral que corresponda. Durante el proceso electoral, y en la etapa de precampaña, el IFE administra y distribuye 30 minutos en cada estación de radio y televisión entre los órganos electorales para la emisión de su propaganda institucional. En campaña, distribuye 7 minutos. No obstante la puntualidad con la que el modelo asigna los tiempos, hacen falta reglas precisas para determinar la forma de distribuirlos entre las instituciones electorales federales y estatales, lo cual es inadecuado al no garantizarse la equidad en la distribución que sí existe en otros extremos del modelo.

Este es probablemente uno de los efectos negativos de haber consolidado la regulación del acceso a medios de comunicación en un código —el Cofipe- dirigido a regular las campañas electorales en el 
ámbito federal, así como una consecuencia de conferir el monopolio de la administración de los tiempos de Estado en radio y televisión al IFE. Es evidente que en la construcción del modelo primó una óptica contraria a la lógica de la organización electoral de nuestro país - asentada en la descentralización de la competencia electoral compatible con el modelo de Estado federal- que, de entrada, discriminó la relevancia de las campañas electorales de los estados en beneficio de las campañas federales.

El modelo debe garantizar también la socialización de mensajes políticos diversificados en función del tipo de elección de que se trate. Así como el Cofipe confiere a los partidos políticos el derecho de decidir libremente la asignación de sus spots electorales a la campaña presidencial o legislativa, siempre y cuando se obliguen a destinar, al menos, el 30\% de los mensajes a una de ellas, convendría reflexionar sobre la oportunidad de establecer una norma similar para garantizar el uso de tiempos en radio y televisión para la emisión de mensajes vinculados a las campañas legislativas, de gobernador y de integrantes de los municipios.

Lo anterior serviría de acicate para que los partidos políticos se obliguen a la transmisión de propaganda electoral con contenidos vinculados al ámbito específico de cada elección estatal, dando oportunidad a los ciudadanos de conocer las ideas y propuestas que para la realidad local formulan los partidos políticos, de conformidad con la naturaleza del puesto a elegir.

\section{Conclusiones}

1. El ejercicio de la libertad de expresión es consustancial al enriquecimiento del sistema democrático en tanto permite socializar mensajes de contenido político, difundir programas, ideologías y plataformas, confrontar ideas y propuestas de campaña, ejercer la crítica hacia los miembros de la clase política y los partidos políticos, debatir en torno a los resultados de la gestión pública, transmitir spots con voces o imágenes propagandísticas, enviar información con contenido electoral, entrar en diálogo directo con los candidatos y sus partidos y, en el extremo, posibilitar la expresión de las preferencias políticas mediante el ejercicio directo del sufragio. 
2. A cinco años de distancia la ponderación del funcionamiento y los resultados arrojados por el modelo de comunicación político-electoral introducido por la reforma electoral de 2007, conducen a señalar que se ha incorporado con éxito al andamiaje electoral mexicano. No obstante, si advertimos que es un modelo orientado a permitir más y mejores canales para la deliberación pública, el contraste de opiniones y propuestas políticas, el envío de información de contenido político y la socialización de mensajes dirigidos a influir en la voluntad del ciudadano-elector, es preciso señalar que contiene elementos que no favorecen la fluidez, flexibilidad, oportunidad y maximización de la libertad de expresión en el contexto de la comunicación política.

3. Como cualquier otro derecho, la libertad de expresión se encuentra sometida a márgenes de ensanchamiento o modulación de conformidad con la naturaleza, el papel, la función y el influjo que ejercen otros derechos, principios y valores dentro de cada sistema constitucional. La reforma electoral de 2007, trajo consigo una intervención fuerte del legislador constitucional mexicano al ámbito de cobertura de la libertad de expresión, justificada en el significativo papel que el principio constitucional de equidad ha adquirido al interior de la función electoral de nuestro país.

4. Contrario a lo que se ha sostenido en diversos ámbitos, la reforma electoral no "vulnera" ni "atenta" contra la libertad de expresión; más bien la modula o delimita. No la ha transgredido, quebrantado o vulnerado, sino que ha procedido a determinar sus contornos jurídicos, es decir, a fijar la extensión y los alcances de su cobertura jurídica. Ningún derecho o libertad representa un derecho absoluto y la libertad de expresión no es la excepción.

5. El diseño institucional del modelo de comunicación políticoelectoral advierte deficiencias que no favorecen, e incluso obstaculizan, la manifestación de las ideas y su oportuna socialización en el ámbito electoral.

El tiempo que el Estado confiere a los partidos políticos y las instituciones electorales, en vez de utilizarse dentro de un abanico de formatos para la comunicación, quedó drásticamente reducido a un formato casi único que terminó por repartirlo en spots de breve duración. En la decisión de privilegiar la fluidez o la predeterminación del contenido de los mensajes políticos, el legislador optó por esta última posibilidad. $\mathrm{Al}$ respecto, se deben madurar formatos que posibiliten una comunicación más fluida con la intención de enriquecer la calidad de la com- 
petencia política, que doten de mayor dinamismo y oportunidad política al desarrollo de las campañas, aproximen un mayor volumen de información al ciudadano y mantengan la atención del electorado en un contexto en el que la constante repetición de dichos mensajes en la dinámica de la campaña produce una saturación audiovisual que en el corto y mediano plazo, puede generar repercusiones negativas.

6. La "constitucionalización" del modelo de comunicación políticoelectoral trajo consecuencias muy particulares para la permanencia, estabilidad e, incluso, aceptabilidad del modelo, pero también para su extrema rigidez y la dificultad de su cambio, acomodo y adaptación. Si bien la Constitución representó el mejor pedestal para enviar un mensaje claro de reivindicación de los espacios políticos perdidos por la representación popular y para afirmar la supremacía de la representación política sobre el poder de las grandes compañías de radio y televisión, lo cierto es que ha producido una "rígida regulación" del "periodo", la "duración", el "formato", los "sujetos beneficiarios" y el "ámbito de difusión” de los mensajes de contenido político-electoral, apartando al modelo de la flexibilidad necesaria para utilizar los tiempos de Estado en esquemas menos rígidos y con mayor capacidad de adaptación a las distintas necesidades de la comunicación política.

7. El modelo instaurado en la reforma de 2007, basado en el formato del spot, presupone una visión vertical de comunicación política. El rasgo unidireccional que introduce, al estar concebido para una plataforma de mensajes de contenido breve, carente de verdadera información para el ciudadano, y con una construcción desde la lógica del marketing político, lejos está de alentar la deliberación en el entorno de la competencia política, ni la réplica en el ámbito de las ideas, propuestas o compromisos que allí se generan. No favorece, en consecuencia, un proceso comunicativo abierto, fluido y dialéctico, ni la instauración de campañas deliberativas o replicantes, mucho menos flexibles y espontáneas en donde la difusión de promocionales pueda ser ajustada mediante criterios de oportunidad política. Al efecto, es necesario generar una comunicación más horizontal, en donde el ciudadano se considere no solamente receptor, agente activo del proceso comunicativo, con capacidad para generar información, debatir, replicar y participar decididamente en la deliberación política, y movilizarse al interior de las campañas electorales.

8. El modelo de comunicación político-electoral está rígidamente asentado en el monopolio de la participación política de los partidos po- 
líticos. No es consecuente con la reforma política de agosto de 2012 que incorporó las candidaturas independientes al sistema electoral, lo que introduce un rasgo de exclusión y falta de integralidad que debe ser puntualmente atendido para incorporar esta nueva modalidad de mensajes al circuito de la comunicación política. El modelo contiene hoy en día una omisión de relevancia; mientras impida el flujo de información de contenido político entre todos los actores relevantes del escenario público no podrá considerarse integral, abierto, plural y omnicomprensivo.

9. La distribución de los tiempos de Estado en radio y televisión actualmente vigente confiere características de inequidad al modelo de comunicación político-electoral en tanto realiza la distribución de espacios diferenciados bajo el criterio del "tipo de elección" federal o estatal, privilegiando a la primera porque la presidencial es la elección de mayor significación política. No obstante, el número de cargos de elección popular en los estados de la República, así como la reciente reforma a favor de las candidaturas independientes obliga a reflexionar en medidas de compensación que equilibren el tiempo que se destina a las campañas estatales, teniendo en cuenta que, derivado de su naturaleza, es muy probable que sea en este ámbito en donde se produzca una mayor participación de candidaturas independientes. 